\title{
De sønderjyske forårsmøder
}

\section{af Harald Jørgensen}

De såkaldte »forårsmøder « fandt sted fra $1890 \mathrm{og}$ indtil 1. Verdenskrig. Her mødtes fremtrædende personligheder fra sønderjysk interesserede foreninger $\mathrm{i}$ kongeriget med ledende mænd fra det danske arbejde i Sønderjylland. Man drøftede de vigtige nationalpolitiske spørgsmål og larte hinanden at kende.

I foreningen TO LøVER's protokoller kan man læse om forhandlingerne. Fhv. landsarkivar, dr.phil. Harald Jørgensen giver på dette grundlag et billede af mange af de sager, som tegnede den sønderjyske sag omkring århundredskiftet.

I oktober 1888 enedes en lille gruppe studenter og yngre kandidater med tilknytning til den konservative "Studenterforening" om at oprette en særlig sammenslutning, hvis formål skulle være at vedligeholde interessen i den danske offentlighed for den nationale kamp i Sønderjylland og at støtte sønderjyderne i den seje modstand mod den voksende germanisering. Man henvendte sig til den meget nationalt interesserede og ansete højesteretssagfører Sophus Nellemann (1833-1915) om at påtage sig formandskabet. Samtidig opfordrede man den daværende gehejmearkivar, senere rigsarkivar A. D. Jørgensen (184097) til at indtræde $\mathrm{i}$ bestyrelsen. Begge modtog opfordringen, og den nye forening fik navnet TO LØVER. Man var også enige om at indlede et praktisk samarbejde med den allerede eksisterende tilsvarende forening med tilknytning til den radikale studenterforening, som gik under navnet $4 \mathrm{~S}$ eller STUDENTERSAMFUNDETS SøNDERJYSKE SAMFUND. Indtil sin død var ADJ. et aktivt medlem af bestyrelsen for TO LøVER, ligesom han formåede at få konservative og radikale akademikere til at samles om en fælles indsats for den nationale sag. Provisorietiden havde ellers gravet en næsten uoverstigelig kløft mellem konservative og venstresindede akademikere. ${ }^{1}$

Et af ADJ.s første initiativer indenfor det således etablerede samarbejde var et forslag om oprettelse af et sønderjysk historisk tidsskrift, hvis første hefte udkom i 1889, med titlen "Sønderjyske Årbøger «. ${ }^{2}$ Et andet initiativ gik ud på, at man skulle arrangere såkaldte »forårsmøder «, med deltagelse af inviterede sønderjyder og repræsentanter for forskellige kongerigske sønderjyske foreninger. Formålet skulle være at erfare de lokale tillidsmænds syn på de initiativer, som foreningerne i kongeriget hidtil havde taget til støtte for nationalitetskampen. Det kunne også være praktisk i fællesskab at diskutere eventuelle lokale ønsker om nye foranstaltninger. De to foreningers bestyrelser var enige om, at man skulle indkalde til sådanne møder - om muligt hvert forår - og at de 


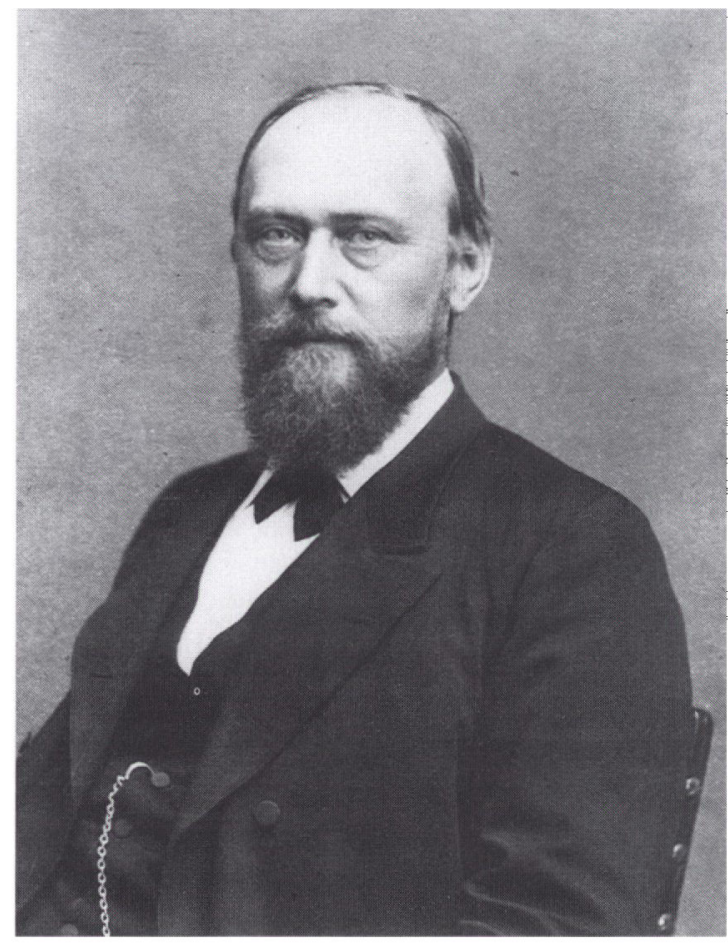

Rigsarkivar A. D. Jorgensen (1840-97) stod bag de sakaldte "forårsmoder" og utallige andre initiativer til stotte for de danske syd for Kongeåen. Historiske Samlinger for Sonderjylland.

skulle strække sig over to eller tre dage. De sønderjyske gæster skulle komme til København lørdag aften med toget og indkvarteres privat. Man kunne så benytte søndagen og evt. mandagen til de fortrolige drøftelser. Der skulle også foranstaltes en fælles festlig sammenkomst, der $i$ overensstemmelse med sædvanlig sæd og skik $\mathbf{i}$ akademiske kredse burde afsluttes med et punchesold. Ved denne lejlighed skulle der holdes taler og synges.

Det første forårsmøde løb af stabelen 29.-31. marts 1890. Til dette møde skrev Johan Ottosen sangen "Det haver så nyligen regnet, og de træer de dryppe endnu«. Sangen blev modtaget med stor begejstring og er jo fra da af og stadig at betragte som de danske sønderjyders slagsang. Tilsvarende møder arrangeredes i 1891, 1892, 1893 og 1894. I 1895 besluttede man ikke at afholde noget møde, da der ikke forelå aktuelle problemer til debat. Man frygtede også for, at møderne skulle få en for »triviel karakter «. ${ }^{3}$ Denne frygt forduftede imidlertid hurtigt, og i 1896 kaldtes der påny til møde. Sålænge ADJ. levede, holdtes de fortrolige møder i Rigsarkivet, formodentlig på læsesalen i den gamle gehejmearkivbygning. ADJ.'s død i 1897 markerer afslutningen på den 
første epoke i møderækken. Modsætningerne mellem de kongerigske foreninger skulle i fremtiden træde klarere og klarere frem.

I det til Rigsarkivet af TO LØVER afleverede foreningsarkiv findes fra årene 1888-1918 to forhandlingsprotokoller, hvori er indført ikke blot referater af foreningens egne bestyrelsesmøder, men også af de med $4 \mathrm{~S}$ afholdte fallesmøder og referater af forårsmøderne. ${ }^{4}$ Det fremgår heraf, at man på bestyrelsesmødet 3. febr. 1890 vedtog at arrangere et møde i København med delegerede fra Sønderjyllands forskellige egne for at forhandle med dem om aktuelle emner. Det besluttedes endvidere at overdrage Den nordslesvigske Vælgerforenings bestyrelse at udpege de delegerede. ${ }^{5}$

\section{Deltagerne}

I et brev fra ADJ. til Vælgerforeningens sekretær, redaktør H.P. Hanssen-Nørremølle, dat. 25. febr. 1890, får man lidt mere at vide om baggrunden for indkaldelsen til det planlagte møde. ${ }^{6}$ Det hedder her: "Vi har her i den senere tid drøftet planen med et besøg herovre af en 8-10 mand fra alle Nordslesvigs egne til forhandling med de herværende foreninger. Frøken Anna Thalbitzer har jo agiteret derfor et helt år og derved måske fremkaldt en stemning hos mange derovre, som der må tages hensyn til. ${ }^{7} \mathrm{Jeg}$ mener nu, at vi skal opfordre Reimers til i forening med Michelsen, som formænd for de to foreninger, at udpege, hvem de vil have med, således at de forskellige egne og de forskellige grupper og synsmåder repræsenteres. Opholdet her skulle vare en 3 dage, $\mathrm{i}$ hvilken tid vi kunne få et par forhandlinger, et par foredrag og et fællesmøde. Det kunne da være heldigt at få diskussion om adskillige ting: biblioteket $\mathrm{i}$ Flensborg, årbøgerne, Søndagsbladet, børneundervisningen m.m. Det måtte jo ikke være for opsigtsvækkende, og det måtte fremfor alt være pålidelige mænd, som kom. Vil De foreløbig tale med Reimers om det? Det skal ikke gerne vare for længe, for det bliver sat $i$ vark. Med venlig hilsen Deres J.«

Brevet har en efterskrift: »Blandt dem frk. Thalbitzer har talt til og opfordret til deltagelse er Skrumsager, Wolff, Poulsen, min broder, Madvig osv. (men det ved Reimers nok)«. Af de nævnte personer kom alle til det første forårsmøde med undtagelse af ADJ.'s ældre broder, farver A. F. Jürgensen, Gråsten. Han deltog dog i enkelte af de senere møder.

De indbudte gæster ankom til København lørdag aften d. 29. marts, og både søndag og mandag var optaget af forhandlinger. Der deltog 8 sønderjyder, hvoraf flere også mødte til en del af de efterfølgende møder. Blandt deltagerne var slagtermester P. Reimers (1826-1922) som formand for Vælgerforeningen og gårdejer Jacob Michelsen, Kolstrup (1845-99) som formand for Sprogfor- 
eningen. Reimers kom dog kun sjældent, idet red. H.P. Hanssen-Nørremølle (1862-1936) som foreningens sekretær efterhånden indtog hans plads. Læge P. A. Madvig fra Haderslev (1816-99), som sad både i Vælgerforeningens og Sprogforeningens styrelse, var en flittig deltager i møderne og tog ofte ordet. Det samme gjorde proprietær H. A. Knudsen (1831-1917), der ejede både Trøjborg og Visby Hedegård, og som blev en naturlig repræsentant for Vestkysten. Han lod ofte sin røst lyde under debatterne. Gårdejerne P. Skau, Bukshave (1825-1917), J. N.H.Skrumsager (1841-1921) fra Københoved og C.P. Wolff, Gammelgab (1842-1913) hørte både til de faste støtter og aktive deltagere. Det samme var tilfældet med rigsdagsmand Gustav Johannsen, Flensborg (18401901).

Fra indbyderne mødte først og fremmest repræsentanter fra bestyrelserne for de to akademiske foreninger. TO LØVER var repræsenteret ved Nellemann, ADJ., cand.theol. J.M. Hertz (1863-1954), cand.theol. H.P. Hansen (1867-1942) og cand.theol. Laust Moltesen (1865-1950). 4 S. mødte med professor Harald Høffding (1843-1931), cand.mag.'erne Johan Ottosen (1859-

Historikeren Johan Ottosen (1859-1904). Han skrev sangen "Det haver så nyligen regnet" til det forste forårsmode $i$ marts 1890. Historiske Samlinger for Sinderjylland. 
1904) og H. V.Clausen (1861-1937), højskoleforstander Fred. F. Falkenstjerne (1854-96) og protokolsekretær Poul Sveistrup (1848-1911). Som gæst havde man desuden inviteret den meget sønderjysk interesserede generalauditør H.C. Steffensen (1837-1912). Foruden de af de akademiske foreninger udpegede delegerede til det første forårsmøde kom ligeledes tandlæge Axel Carstens (1847-1927) som formand for De samvirkende sønderjyske Foreninger og murermester Karl Kruse (1840-1900) og vinhandler Johan Schrøder (1838-1920) fra Sønderjysk Samfund. Medens de sønderjyske repræsentanter havde været i mindretal overfor de kongerigske delegerede, øgedes i løbet af 1890 'erne ikke blot antallet af deltagere, men i 1897 var der så nogenlunde ligevægt mellem de to grupper, nemlig 19 nordslesvigere overfor 22 kongerigske. Adskillige af de fremmødte i 1897 havde deltaget trofast i de forløbne år, men også nye ansigter sås, og de fortsatte med at komme også efter århundredskiftet. Af sønderjyder kan bl.a. nævnes rigsdagsmand Gustav Johannsen (1840-1901), red. Jens Jessen (1854-1906) og grosserer Julius Nielsen, Damager (1848-1920). Blandt Københavnerne kan anføres den senere overretssagfører $O$. Th. Krarup (1833-1912), departementschef Anders Dybdal (1852-1915) og professor Camillus Nyrop (1843-1918). Foruden de allerede nævnte kongerigske foreninger sendte nu også foreningen Dannebrog og Sønderjysk Samfund i Kolding repræsentanter til forårsmøderne. Fra Kolding deltog således forfatteren Morten Eskesen (1826-1913).

\section{Mødeemner 1890-97}

Til belysning af, hvad der skete på de 6 møder, som afholdtes $\mathrm{i}$ årene 1890 97, findes mødereferater i den bevarede protokol. Det er ikke noget stenografisk referat af, hvad der blev sagt, men et mere eller mindre udarbejdet sammendrag af de førte forhandlinger. Formodentlig er det blevet til på den måde, at man anmodede et bestyrelsesmedlem om at referere. Han har derefter taget sine notater og senere renskrevet dem og indført dem i protokollen. Der har ikke været tale om at forelægge dem i de respektive bestyrelser, og de ses ikke godkendt. Ud over disse referater findes så godt som intet andet kontrolmateriale. De bliver derfor hovedkilden til en skildring af modernes indhold. ${ }^{8}$

Ved tre af møderne i årene 1890-97 kender vi navnene på referenterne. Ved det første møde varetog Laust Moltesen hvervet, medens dr. H. L. Møller referede forhandlingerne i $1892 \mathrm{og} 1893$. Med hensyn til periodens øvrige referater er forfatteren ukendt. Enkelte referater er ret summariske og kortfattede. Det kan skyldes, at der ikke har været meget at berette, eller at diskussionslysten 
har været begrænset. Mødereferatet fra 1897 er til gengæld ret udførligt, og man får et ganske godt indtryk af de forskellige indlæg.

Man bevæger sig formodentlig på nogenlunde sikker grund, når man ønsker at fastslå, hvilke spørgsmål man diskuterede. Helt sikker kan man dog ikke altid være. Som punkt 4 på dagsordenen for forhandlingsmødet 3. april 1892 var optaget en meddelelse fra $\mathrm{H}$. V. Clausen om hans igangværende statistiske undersøgelser af ejendomsforholdene i Nordslesvig, men det er ikke optaget i referatet. Om referenten har glemt det, eller om der findes en anden grund til udeladelse må stå hen.

Formålet med forårsmøderne var i første række at få en debat igang med de lokale ledere om de nationale opgaver, som de kongerigske foreninger havde planlagt at give støtte. En af de vigtigste var at udbrede lødig dansk litteratur til hjemmene i Nordslesvig og hermed sikre, at lokalbefolkningen havde mulighed for at følge med i den danske litteraturs udvikling. I denne sammenhæng var der enighed mellem parterne om, at man måtte støtte det arbejde, som den i 1880 i Aabenraa stiftede Sprogforening havde sat i gang med oprettelse af lokalbiblioteker ud over landsdelen, og disses fortsatte forsyning med nye bøger. Atter og atter tog forårsmøderne denne vigtige bibliotekssag op til drøftelse. Desuden gjorde man et praktisk arbejde for at få indsamlet den fornødne litteratur i kongeriget og få afsendt bøgerne til Aabenraa, hvor Sprogforeningen herefter tog sig af det videre fordelingsarbejde. Den underafdeling af foreningen TO LØVER, som i 1896 stiftedes af konservative studenter under navnet Heimdal, fandt her en praktisk opgave at løse.

I forlængelse af det allerede begyndte biblioteksarbejde fremdrog ADJ. på forårsmødet i 1890 spørgsmålet, om man ikke skulle oprette et centralbibliotek i Sønderjylland, hvor den lokale befolkning kunne låne først og fremmest litteratur vedr. Sønderjyllands historie samt lødig dansk skønlitteratur. På mødet blev det foreslået at indrette Gustav Johannsens villa »Margrethesminde« $i$ Flensborg til domicil for et sådant bibliotek. Herom førtes en livlig debat, idet gårdejer Skau og godsejer Knudsen støttede Flensborg-tanken, medens pastor Poulsen og slagtermester Reimers talte for Aabenraa. Man motiverede dette ændringsforslag med, at Aabenraa var det sted, hvor man normalt samledes til politiske møder. Desuden fandt man, at "Margrethesminde « lå lidt afsides i Flensborg by. Resultatet blev, at man godkendte at indrette biblioteket her, og at man engagerede Gustav Johannsens datter Alexandra Johannsen (18641927) til at bestyre den planlagte bogsamling. Med interesse modtog man på de efterfølgende forårsmøder meddelelser om brugen af det danske centralbibliotek i Flensborg. Det kan ikke undre, at det navnlig var den bosiddende befolkning i Flensborg, som fandt vej til "Margrethesminde«. Det var især afskedigede lærere, som i deres otium havde taget ophold i Flensborg, som 
havde glæde af det. I Nordslesvig var det først og fremmest beboere i Haderslev vesteramt, som var de flittigste benyttere, medens udlånet til Aabenraa amt var mere beskedent. Med hensyn til Tønder amt kunne man et enkelt år berette, at udlånet til beboere her var $\mathrm{i}$ glædelig stigning.

Et særligt litterært foretagende, som også ofte kom til debat, var det historiske tidsskrift, Sonderjyske Arboger, hvortil ADJ. som før nævnt havde taget initiativet i 1888-89. Herom førtes en ret livlig debat, hvori Poulsen, Skau og Knudsen deltog med flere indlæg. Poulsen mente ikke, at man foreløbig kunne vente mange sønderjyske bidrag, da man i første omgang måtte koncentrere sig om selve nationalitetskampen. Wolff hævdede, at der måtte gøres en indsats for større udbredelse af tidsskriftet, hvortil Skau replicerede, at bønder »køber ikke bøger«. Nogle syntes også at tidsskriftet var for dyrt, og man appellerede til Sprogforeningen om at agitere for dets udbredelse. Høffding blandede sig $\mathrm{i}$ diskussionen med en bemærkning om, at man ikke måtte undervurdere værdien af lokale bidrag, og Skrumsager understregede, at Årbøgerne måtte få en mere officiel opgave, nemlig at bringe biografier af fremtrædende sønderjyder. Trods en noget afventende holdning overfor tidsskriftet mente ADJ. at kunne registrere en vis positiv indstilling. Med årene kunne han også konstatere et stigende abonnementsantal. Gustav Johannsen kunne berette, at også tyske kredse (bl.a. den tyske avis Kreuzzeitung) havde bemærket det danske tidsskrift.

Et andet spørgsmål, som optog forårsmøderne var, hvad man kunne gøre for at neutralisere den preussiske skolepolitik, som systematisk havde indskrænket dansk som undervisningssprog i folkeskolen. Som det sidste skridt var det ved en anordning af 10 . dec. 1888 bestemt, at der kun måtte undervises nogle få timer om ugen $\mathrm{i}$ religion på dansk. Under indtryk heraf rejste ADJ. på forårsmødet i 1891 en debat om betydningen af at støtte den igangværende vandrelcerervirksomhed. Efter hans mening var det en vandrelærers opgave både at sørge for undervisning i de elementære skolefag $\mathrm{og}$ at give interesserede forældre den fornødne belæring, således at de kunne videreføre deres egne børns undervisning. Man skulle endvidere drage omsorg for, at de fornødne danske læsebøger var til disposition. Man måtte ligeledes tænke på at få tilvejebragt en særlig stavebog, som tog hensyn til, at både lærere og børn talte sønderjysk. Indlederen gjorde opmærksom på, at han havde formået filologen P.K.Thorsen (1851-1920) til at udarbejde en vejledning i forholdet mellem dansk rigssprog og sønderjysk, som skulle medfølge enhver læsebog, som uddeltes i de sønderjyske hjem.

Indledningen gav anledning til en ret langvarig debat, og de forskellige synspunkter er ganske udførligt refereret. Enkelte af deltagerne gav oplysninger om specielt vandrelærer Kasper Jensens (1858-1930) igangværende virksom- 


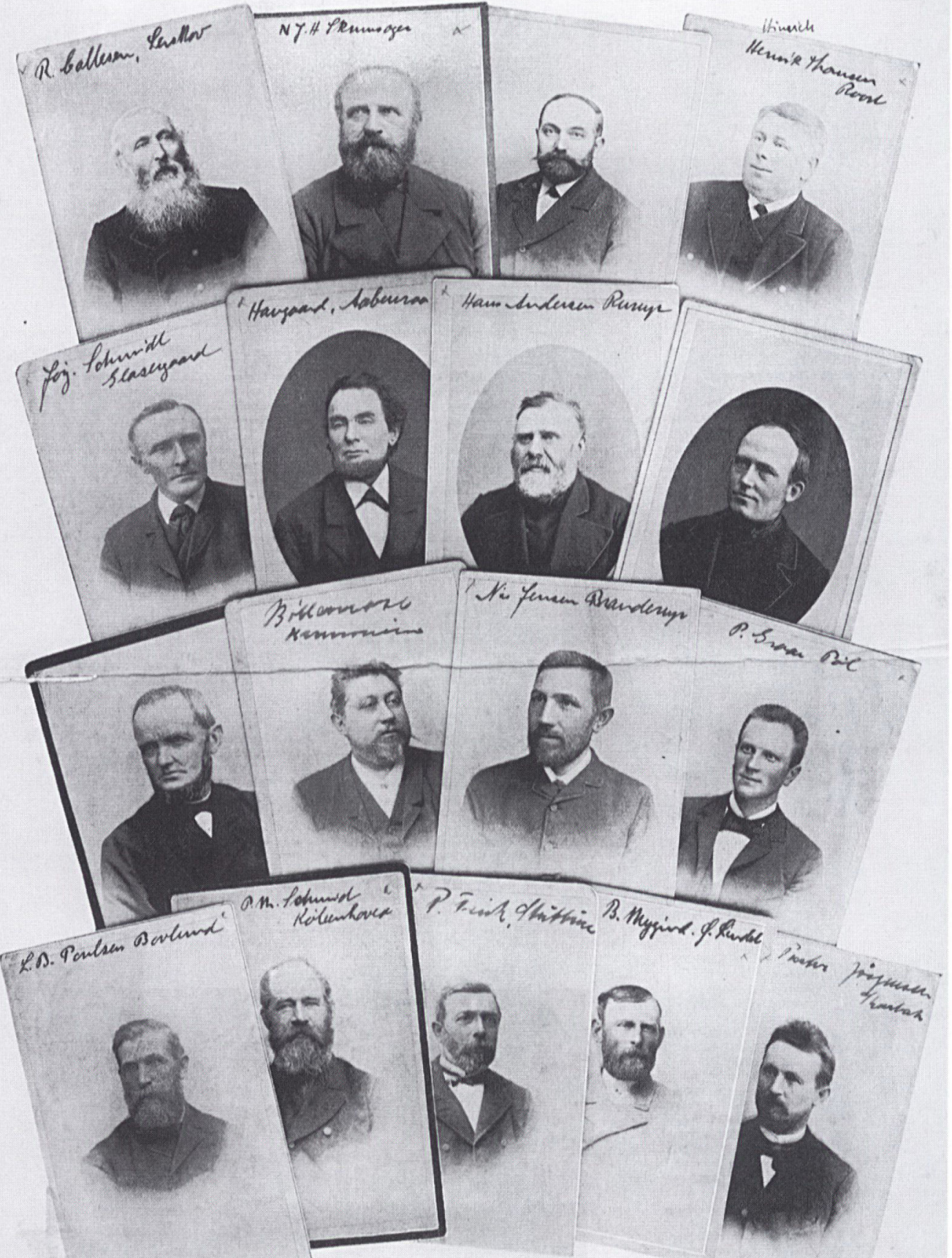


hed. Red. H.P. Hanssen kunne således meddele, at han i perioden 1/9 1890-31/ 31891 havde undervist 44 børn i forskellige egne, og han oplæste flere breve fra tilfredse forældre, der havde været meget glade ved Kasper Jensens indsats. Også andre af mødedeltagerne tilkendegav tilfredshed. Gårdejer Andr. Thyssen Hansen (1834-1914) tog til orde for, at der i hver landsby burde være en lærerinde, hvilket gårdejer Hinrich Thomsen-Roost (1845-1919) dog måtte tage afstand fra, da politimyndighederne sikkert ville skride ind. P.Skau udtalte en vis ængstelse for, at børnene blev overbelastet, hvis de både skulle følge den normale skoleundervisning og samtidig nyde godt af en vandrelærers hjemmeundervisning. Det foranledigede Wolff-Gammelgab til at foreslå, at hjemmeundervisningen blev givet børnene, før de begyndte i den offentlige skole, og at man måske kunne indrette en art børnehaver. Det syntes både Skrumsager og Matthias Andresen (1858-1916) var en god idé, idet man sagtens ville være istand til at lære børnene at stave og læse, før de skulle i skole. Spørgsmålet om hvem der skulle bestride de hermed følgende udgifter førte til, at gårdejer Michelsen, Kolstrup udtrykte som sin mening, at det måtte Sprog- og Vælgerforeningen være de nærmeste til at betale, hvilket H.P. Hanssen fandt var en dårlig idé, da foreningernes regnskaber ikke kunne holdes borte fra autoriteterne. Hertil replicerede både ADJ. og Wolff, at det måtte man nok bogholderimæssigt kunne finde på at kamuflere, men H.P. Hanssen holdt på sit. Det kaldte tømrermester Harald H. Kayser (1817-95) ind i debatten med en bemærkning om, at man var altfor ængstelig. Myndighederne var i forvejen ganske klare over, at sønderjyderne modtog kongerigske bidrag til deres nationale kamp. Også Nellemann og Høffding ytrede sympati for, at man aktivt støttede vandrelærernes virksomhed, og man enedes om at bede Sprogforeningen om at udarbejde et nærmere forslag til, hvorledes hjælpen kunne organiseres.

Vandrelærernes virksomhed kom igen til debat i 1892 og 1894, hvor man gav en række praktiske oplysninger om de forskellige læreres virksomhed. I 1892 kunne H.P. Hanssen således meddele, at den kvindelige vandrelærerinde Henriette Gubi (1856-94) havde kunnet virke uden myndighedernes generende indgriben, medens man havde standset Kasper Jensens undervisning. Dette ville man imidlertid prove lovligheden af. I 1894 kunne man oplyse, at vandrelærervirksomheden var fuldt genoptaget, og at man i den senere frimenighedspræst Thade Petersen (1866-1949) havde fundet en mand, der var villig til at give aftenundervisning under dakke af offentlige foredragsmøder, i hvilke

Illustreret Tidende gengav i 1899 portratfotos af en lang rakke fremtradende danske senderjyder. En meget stor del af disse folk genfindes $i$ deltagerlisterne fra forärsmederne. Historiske Samlinger for Sonderjylland. 
unge over 16 år havde tilladelse til at deltage. Nogen større diskussion gav disse meddelelser dog ikke anledning til.

På forårsmødet i 1893 kunne frimenighedspræst L. B. Poulsen (1840-1919) give mødedeltagerne den glædelige meddelelse, at den preussiske skolepolitik havde ført til oprettelse af en ny national organisation. På et møde i Skærbæk 30. nov. 1892 havde man stiftet Den nordslesvigske Skoleforening, hvis formål var at indsamle penge, således at man kunne sende unge sønderjyder på efterskoler i kongeriget og med tiden også på danske høj- og landbrugsskoler. Foreningen havde haft den lykke at modtage så mange indmeldelser, at medlemstallet allerede nu oversteg de to andre hæderkronede nationale foreningers. Som formand var valgt gårdejer Jens P. Jensen, Lovrup (1841-1923), der i 1899 afløstes af gårdejer $A$. Thyssen Hansen. Som kasserer og praktisk administrator var udpeget gårdejer $\mathbf{H}$.Thomsen-Roost. Både Thyssen Hansen og H. Thomsen blev i 1890 'erne flittige deltagere i forårsmøderne. Skoleforeningen var $\mathrm{i}$ løbet af kort tid $\mathrm{i}$ stand til at sende årligt mellem $200 \mathrm{og} 250$ unge af sted nordpå. Haderslev amt leverede de fleste elever, medens der kom væsentlig færre ansøgninger fra Aabenraa amt. I bunden lå, som man kunne vente det, ansøgninger fra Flensborg amt. I 1894 kunne man herfra kun sende en enkelt af sted. I 1898 var det steget til 7.

Allerede ved det første møde rejste Nellemann spørgsmålet om støtte til unge sonderjyders akademiske uddannelse. Det var en sag, som navnlig de kongerigske akademikere tillagde en ikke ringe betydning og gerne ville støtte. Forslaget vandt sympati hos nogle af de lokale repræsentanter, men andre mente, at man måtte koncentrere sig om de unge mennesker, som søgte videre udvikling på høj- og landbrugsskoler samt håndværkerskoler. Tilhængere af forslaget var klare over de mange problemer en udvælgelse ville foranledige, og man var enige om, at de pågældende efter endt uddannelse skulle forpligte sig til at tage varigt ophold i Nordslesvig. Gårdejer Skau støttede varmt forslaget, medens Skrumsager var mere betænkelig. Han kunne ikke prioritere denne tanke særlig højt. Det var vigtigere, at man satsede på at hjælpe de almindelige unge. Man risikerede ellers let, at »befolkningens intelligens sank under tyskernes.« I øjeblikket stod den højere, og det skulle den vedblive at gøre. Pastor Poulsen tilsluttede sig Skrumsager og henviste til de gode resultater, man havde nået ved at sende unge nordslesvigere på danske højskoler. Nellemann mente, at man nok kunne arbejde på begge fronter samtidig. Både Falkenstjerne og Høffding fremhævede betydningen af, at Nordslesvig kunne forsynes med danske akademikere. Høffding så dog ikke bort fra, at man måtte være indstillet på visse skuffelser, og han tilføjede, at det nok var rigtigt at lade de pågældende unge opholde sig en kortere tid også ved et dansk universitet.

Spørgsmålet kom op ved flere lejligheder i den kommende tid, og på forårs- 
mødet i 1897 understregede ADJ. atter betydningen af, at landsdelen kunne blive forsynet med dansksindede akademikere. Indlederen var klar over, at Skoleforeningen ikke kunne støtte denne sag, men det ville være et alvorligt nationalt tab, hvis en egnet ung nordslesviger ikke kunne få hjælp til en akademisk uddannelse. Muligvis kunne Sprogforeningen skaffe de fornødne midler.

Det kan ikke undre, at Sprogforeningens særlige repræsentant på mødet M. Andresen kraftigt tog til genmæle mod dette forslag, som ville formindske småkårsfolks mulighed for at låne bøger og $\mathrm{i}$ det hele taget modtage nyttig dansk litteratur. På den anden side støttede H.P.Hanssen ADJ. Naturligvis burde man ikke begrænse Sprogforeningens virksomhed, men denne havde dog modtaget betydelige gaver fra privatfolk, bl.a. en årlig bevilling på 810.000 mark fra baron Stampe til Nysø foruden en rigelig tilgang af gratis bøger, således at det nok skulle være muligt at frigøre visse midler. H.P. Hanssen gjorde også opmærksom på, at andre nationale minoriteter indenfor det tyske kejserrige tillagde uddannelse af egne akademikere stor betydning, og at der i Nordslesvig i høj grad var brug for videregående uddannelse af unge, som i fremtiden kunne løse vigtige opgaver indenfor bankvæsenet og den opvoksende industri.

Under den videre debat udkastede $\mathrm{ADJ}$ den idé, om man måske i stedet for at yde kontant hjælp kunne give lån, men denne tanke fandt tilsyneladende ingen større sympati. ADJ. gav imidlertid ikke op, og han rejste spørgsmålet, om udsendelse af det særlige Børneblad, der kostede Sprogforeningen godt 2.000 kr., ikke kunne inddrages, eller hvis man stadig tillagde bladet stor betydning, om man ikke kunne forhøje abonnementsprisen eller kontingentet til Sprogforeningen. Naturligvis rykkede Andresen ud til forsvar for Børnebladet, idet han gjorde opmærksom på, at det ved bladets oprettelse var bestemt, at størsteparten af oplaget skulle uddeles gratis. Han gjorde endvidere opmærksom på, at man benyttede bladet til at udskrive emner til de nordslesvigske børns øvelser i at skrive danske stile eller udtrykke sig skriftligt på dansk, hvad de ellers ikke havde store muligheder for at øve sig i. Ikke mindre end ca. 800 børn havde på det sidste besvaret de stillede opgaver. Både H.V.Clausen og Gustav Johannsen fremhævede den nationale betydning af Børnebladet og af stileskrivningen. Gustav Johannsen gjorde endvidere opmærksom på, at der fra tysk side var fremkommet ret så hadefulde kommentarer til Børnebladet, hvilket kunne tyde på, at man tillagde det en ikke ringe betydning for at fastholde den opvoksende ungdom indenfor de danske rækker. H.V.Clausen understregede desuden vigtigheden af, at det var lykkedes at interessere medlemmerne af studenterudvalget Heimdal for at påtage sig arbejdet med at rette de mange stile. Stillet overfor disse oplysninger tog ADJ. sit forslag tilbage, men han sluttede med at udtrykke det stille ønske, "at de nordslesvigske gård- 
mænd efterhånden ville indse deres forpligtelse til at hjælpe med til at holde sådanne foretagender (som Børnebladet) oppe.« Det bør ikke lades uomtalt, at det efterhånden ved økonomisk indsats fra de kongerigske foreninger lykkedes at fremskaffe de fornødne penge til at støtte unge nordslesvigeres akademiske uddannelse. Som eksempler på personer, som støttedes, kan nævnes advokat Chr. Ravn, Flensborg (1877-1964), amtmand Kr. Refslund Thomsen, Aabenraa (1884-1960) og tandlæge Jonathan Smith, Haderslev (1877-1968).

Endnu nogle konkrete sager skal omtales, som optog de forskellige møder. Der var således optantsagen. Flere nordslesvigere, som havde bevaret deres danske statsborgerskab, ønskede nu at blive preussiske statsborgere for at kunne bo og bygge $\mathrm{i}$ hjemstavnen og navnlig deltage i de politiske valg. Der opstod imidlertid vanskeligheder med at få sagerne igennem, og navnlig foregik ekspeditionen meget langsommeligt. På mødet i 1891 satte ADJ. spørgsmålet under debat. For at lette ekspeditionen gennem det danske indenrigsministerium foreslog Nellemann, at man søgte kontakt med en embedsmand i ministeriet, som kunne holde Vælgerforeningen løbende orienteret om de indkomne ansøgninger. H.P. Hanssen foreslog desuden, at man udarbejdede et regulativ med en fortegnelse over de dokumenter, en ansøger skulle møde med. Allerede på det næste årsmøde kunne man berette, at sagerne nu gik hurtigere i København. På den anden side mente man at kunne konstatere en tendens hos provinsregeringen i Slesvig til at trænere sagerne. Det var også fornemmelsen, at den tyske administration viste sig afvisende overfor personer, der boede $i$ et sogn, hvor der var udsigt til, at tyskerne kunne få politisk flertal. På ansøgninger fra et bestemt sogn var der således givet afslag i 18 tilfælde. I 1893 kunne H.P. Hanssen meddele, at der indtil udgangen af 1892 var tilstået preussisk statsborgerskab til 1207 nordslesvigere, og at der endnu var ca. 4.000, som gerne ville skifte statsborgerskab. Selv om der i landdagen var foretaget en direkte henvendelse til den preussiske indenrigsminister, som havde svaret, at han så positivt på de indkomne andragender, mente man dog stadig, at ansøgninger fra byboere og fra sogne med en stærkt blandet befolkning ikke nød særlig bevågenhed hos de lokale autoriteter. Sagerne gik ellers »sin jævne gang«, hævdede man.

På årsmødet i 1897 kom det vigtige jordsporgsmål under debat. Med tyske statsmidler var der sat en aktion i gang i den hensigt at opkøbe danske landejendomme, dels på Als, dels i området Rødding-Skærbæk. Til brug for debatten havde H.P. Hanssen indsamlet et omfattende materiale om truede ejendomme og eventuelle købere. Der var almindelig enighed i forsamlingen om, at det med pekuniær støtte fra kongeriget måtte være de lokale kræfter, som skulle organisere modstanden mod de tyske opkøb. Man enedes om at nedsætte et stort fællesudvalg af nordslesvigere og kongerigske repræsentanter til nær- 
mere at organisere den nødvendige modoffensiv. Den skulle så vidt muligt fremtræde som en forretning og ikke med et altfor tydeligt nationalt præg.

Det andet store spørgsmål, som optog deltagerne på dette møde, var husmandssagen, dvs. forholdet mellem husmænd og gårdejere. Der havde i de forløbne år været organiseret adskillige rejser til kongeriget for nordslesvigske gårdmænd, og navnlig havde forstanderen for Lyngby Landboskole J.C. la Cour (1838-98), der fra sin ungdom var stærkt sønderjysk engageret, interesseret sig varmt for denne opgave. På mødet diskuterede man påny disse rejser, og man spurgte, om det var rigtigt fortsat kun at henvende sig til gårdmandsstanden og nærmest negligere husmænd og arbejdere. Det var nu på tide, at man ændrede holdning. Spørgsmålet var imidlertid, om man skulle organisere rejser, hvori både gårdmænd og husmænd kunne deltage eller, om man skulle holde hver gruppe for sig.

Under den ret langstrakte debat gjorde Madvig sig til talsmand for, at man ikke skilte de to grupper ad, og han fik støtte fra Gustav Johannsen. I det hele taget blev det fra flere sider fremført, at det var kunstigt at foretage denne adskillelse, da mange husmænd var medlemmer af de nordslesvigske landboforeninger. I første omgang tog man dog til efterretning, at Mads Jensen (1839-1909) fra Jegerup havde tilbudt at lede en rejse for 30 husmænd, som i juli måned skulle besøge Askov og Fyn, hvor forstander Alfred Povlsen (18521934) på Ryslinge højskole havde erklæret sig rede til at organisere husmændenes besøg.

Hvad der først og fremmest optog deltagerne i 1890'ernes forårsmøder var en række praktiske problemers løsning i forbindelse med nationalitetskampen. Fra begge sider kunne man fremlægge nye ideer og diskutere mulighederne for at føre dem ud i praksis. Man kunne også holde sig løbende orienteret om resultaterne af de forskellige initiativer. De optagne mødereferater indeholder mange konkrete oplysninger om forholdene i Nordslesvig, som det ikke altid vil være let at fremskaffe fra andre kilder. 1890'erne var både i Nordslesvig og i kongeriget en anspændt tid, hvor modsætningerne mellem forskellige grupper var stærke. Men deltagerne i forårsmøderne synes at have været enige om at holde sig fra partipolitik. Denne politiske linie havde man allerede tidligt fastslået som rettesnor for TO LØVER og 4 S's fælles indsats. Man ville ikke blande sig i Nordslesvigs interne politiske stridigheder. At gøre dette ligger langt ud over, hvad vi har evne eller berettigelse til, udtalte man. I stedet så man det som sin opgave at bidrage til, at »den danske befolkning i Nordslesvig kan blive ved med at søge sin åndelige næring fra moderlandet« og at hindre, wat det skal lykkes dens regering gennem skolen osv. at tilstoppe dens åndelige livskilder.«På intet tidspunkt synes man at have afveget fra denne linie i forårsmødernes første periode. Personlige sammenstød mellem repræsentanterne 


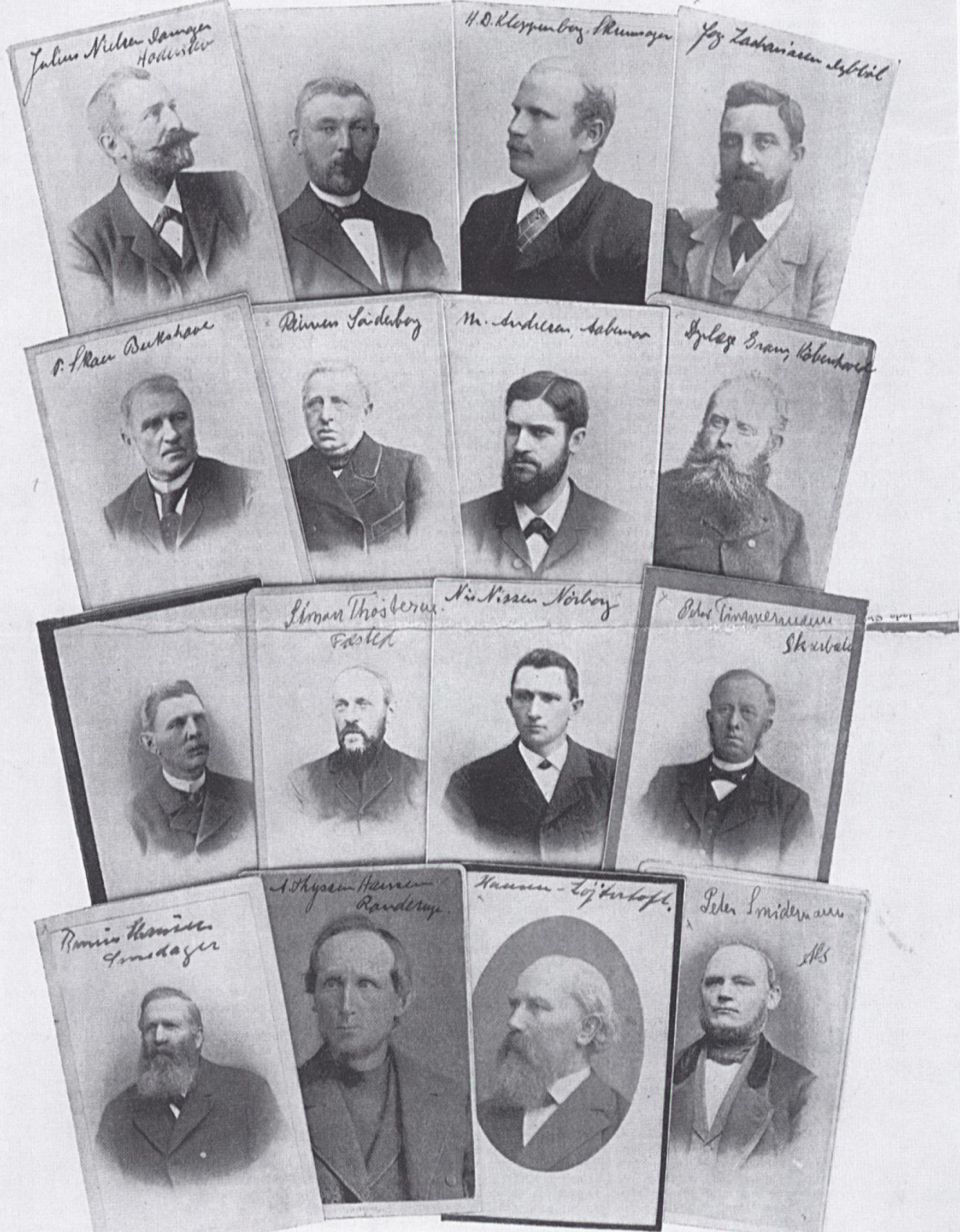


for de to akademikersammenslutninger, som i fællesskab var ansvarlige for forårsmøderne, er ikke konstateret. Det hænger nok i nogen grad sammen med det forhold, at ADJ. nød stor respekt og anerkendelse blandt en række fremtrædende medlemmer indenfor $4 \mathrm{~S}$.

\section{Efter A. D. Jørgensens død}

Det sidste møde ADJ. overværede, var forårsmødet i 1897. Endnu i sommeren 1897 deltog han i bestyrelsesmøderne i TO LØVER, men 5. oktober 1897 døde han. Der skulle ikke gå ret mange år efter hans bortgang, før det kom til et pinligt sammenstød mellem repræsentanterne for de to akademikergrupper ved den festlige afslutning af forårsmødet $\mathrm{i}$ året 1900 . Selv om man endnu nogle år kunne mødes til fælles indsats for den nordslesvigske sag, var der slået et skår i samarbejdet.

Indtil videre fandt forårsmøderne dog sted, således som der var skabt tradition for. De inviterede sønderjyder ankom i løbet af lørdagen, man holdt forhandlingsmøde om søndagen, eventuelt fortsattes om mandagen, og endvidere samledes man til en festlig middag, hvor taler og sang afløste hinanden. $\mathrm{Nu}$ overtog TO LØVER's formand, højesteretsadvokat Nellemann, rollen som samlende midtpunkt, og møderne blev flyttet til Studenterforeningen. Senere henlagdes forhandlingerne til Industriforeningens lokaler på Rådhuspladsen. Det var nødvendigt, da deltagerantallet både fra Nordslesvig og fra de sønderjyske foreninger i kongeriget voksede kraftigt. Til gengæld forsvandt lidt af det intime samvær, der hidtil havde været karakteristisk for møderne. Det var nu kun et mindretal af de fremmødte, som aktivt deltog i forhandlingerne. Det store flertal i begge grupper nøjedes med at lytte.

Man mødte påny til ordinært forårsmøde i 1898, og ganske naturligt mindedes man ved denne lejlighed ADJ. som initiativtager til forårsmøderne. Man enedes om at indsamle midler til et offentligt monument $i$ hovedstaden over den bortgangne. Der fandt også en indsamling sted i Nordslesvig. I 1901 kunne man afsløre en broncebuste, fremstillet af billedhuggeren Vilh. Bissen (18361913). Inskriptionen fortæller, at her står "Sønderjyden A. D. Jørgensen «. Den er rejst ved gavlen af det sjællandske landsarkivs gamle magasinbygning ud mod Jagtvejen. ${ }^{9}$

Uvist af hvilken grund blev der ikke arrangeret forårsmøde i 1899, men man mødtes igen i 1900,1901, 1902 og 1903. Så var der en pause, inden der indkald- 
tes til nyt møde i 1905. Man havde planlagt et møde i foråret 1906, men red. Jessens alvorlige sygdom medførte, at mødet blev skubbet ud til efteråret. Jessen døde 27. juli 1906, og man afholdt intet møde om efteråret. Herefter indkaldtes der til forårsmøde i 1907 og 1909. Man sprang påny et år over og samledes først i 1911. Dette møde synes faktisk at have været det sidste, men der er ikke bevaret noget referat. Det fremgår af foreningens bestyrelsesprotokol, at man på et bestyrelsesmøde 10. marts 1914 besluttede at udsætte et forårsmødes indkaldelse $\mathrm{i}$ hvert fald til efteråret. ${ }^{10} \mathrm{I}$ august 1914 brød som bekendt verdenskrigen ud, og planen måtte definitivt opgives.

Ligesom i den foregående periode er der i TO LØVERS bestyrelsesprotokol optaget referater fra forårsmøderne, men de er ikke så udførlige som tidligere. Mødet i 1898 synes at vare blevet refereret af den unge juridiske studerende, senere kontorchef P. Erasmus Müller (1877-1953), som i en lang årrække var et meget interesseret medlem af TO LØVER. Senere optræder en anden juridisk student, nemlig den senere kontorchef H. Falck (1877-1937). Han virkede fra 1. sept. 1900 som kasserer i TO LØVER og benævnes som regel sekretær for forårsmøderne. ${ }^{11}$

Som regel får man besked om, hvem der var inviteret og kom til stede. Medens der til mødet i 1903 deltog 16 sønderjyder, mødte der i 1905 ikke mindre end 33 og i 1907 36. Blandt deltagerne fra Nordslesvig var først og fremmest de ledende personer indenfor de tre nationale foreninger Sprog-, Vælger- og Skoleforeningen. Endvidere mødte henholdsvis landdagsmand H.P. Hanssen og rigsdagsmand Jens Jessen. Indtil sin død i 1901 var Gustav Johannsen også en trofast deltager. Skal man fremdrage andre nordslesvigere ved navn, må det blive gårdejerne Skrumsager og P. Skau foruden ejendomskommissær J. H. Schmidt, Vojensgård (1857-1948), der også deltog flittigt i debatterne. Ud herover kom der med årene en lang række nordslesvigske gårdmænd, formodentlig tillidsmænd indenfor de næunte nationale foreninger. De kom ikke alle hver gang, men de synes at have skiftet til at møde frem. Muligvis har man indbyrdes været enige om, at så mange som muligt skulle have mulighed for et Københavnerbesøg og lejlighed til at træffe repræsentanter for de kongerigske foreninger. Det kan også nævnes, at ADJ's broder fra Gråsten af og til modtog indbydelsen helt frem til efter århundredskiftet.

Også antallet af repræsentanter fra de forskellige kongerigske foreninger var støt stigende. De havde altid været i flertal overfor sønderjyderne, og de beholdt føringen, selv om antallet af deltagere nærmede sig hinanden. Det betød, at forårsmøderne efterhånden samlede henved 100 personer.

Også blandt de kongerigske deltagere finder man flere, som trofast mødte op hver gang. Således var højesteretsadvokat Nellemann og den senere rektor H.P. Hansen faste deltagere. Fra TO LøVER mødte desuden regelmæssigt 
kredslæge, professor H.A. Nielsen (1850-1932), kirurgen Jonas Collin (18771938) foruden en række yngre juridiske studerende, nemlig medlemmer af studenterudvalget Heimdal. Af og til inviterede man desuden repræsentanter fra foreningens forskellige provinsfilialer.

Bestyrelsen for $4 \mathrm{~S}$ sendte år efter år sin formand professor Harald Høffding (1843-1931). Desuden mødte lektor H.V.Clausen, forfatteren Karl Larsen (1860-1931) og den senere skoleinspektør H. Th. Physant. Som nye deltagere kan nævnes historikerne Aage Friis (1870-1949) - ligeså hidsig radikal som Collin var konservativ - og den senere rigsarkivar Axel Linvald (1886-1965). De samvirkende sønderjyske foreninger havde som regel en talstærk repræsentation, nemlig foruden sin formand tandlæge Axel Carstens, sagfører Mandal Bertelsen (1857-1930), red. Franz v. Jessen (1870-1948) og grosserer Hans H. Sthyr (1868-1944). Også denne sammenslutning indbød skiftende provinsmedlemmer som delegerede.

De tre her nævnte organisationer mødte med de fleste repræsentanter. Også andre foreninger var repræsenteret, f.eks. foreningen Dannebrog med bl.a. direktør N. Bang og tømrermester Olaf Kayser (1856-1925), Sønderjysk Samfund med sin formand professor Camillus Nyrop (1843-1918), grosserer Johs. Schrøder (1838-1920) og oberst Axel Liljefalk (1848-1910) samt Sønderjysk Samfund i Kolding, som i mange år havde været repræsenteret ved folkesangeren Morten Eskesen (1826-1913). Nu mødte bogtrykker Konrad Jørgensen (1849-1921) og højskoleforstander Jac. Appel (1886-1931). Ud over disse foreningsrepræsentanter inviterede man særlige gæster som specialister på nogle af de områder, man diskuterede, f.eks. biblioteksforkæmperen, overlærer Andr. S. Steenberg (1854-1929), pastor H. Mathiesen fra Kristeligt Dagblad, den juridiske professor Henning Matzen (1840-1910) og ved en enkelt lejlighed red. Erik Møller (1879-1962). Det kan iøvrigt nævnes, at man i denne periode oprettede et særligt samarbejdsorgan mellem de kongerigske sønderjyske foreninger, kaldet Timandsrådet. Det fik professor Camillus Nyrop som formand.

\section{Mødeemner efter 1898}

På dagsordenen var der altid to punkter, som interesserede deltagerne i særlig grad, nemlig beretninger fra henholdsvis Sprogforeningen og Skoleforeningen. Sprogforeningen tog sig af »bogsagen«, dvs. at skaffe den fornødne litteratur til de tusind nordslesvigske hjem. Den drivende kraft $\mathrm{i}$ arbejdet var litteraten Mathias Andresen, fra 1899 også formand for foreningen. Arbejdet bestod først og fremmest $i$ at fordele dels indkøbt dansk litteratur dels skænkede 
bøger og blade fra kongeriget til de mange små lokale biblioteker. Desuden fordelte man egnet litteratur til privatfamilier, navnlig med børn. Andresen forestod selv i vid udstrækning indkøb af litteratur, og det skyldtes hans initiativ, at indkøbspolitikken efterhånden blev draget $\mathrm{i}$ en udpræget folkelig retning. Ved flere lejligheder fremkom der på forårsmøderne en ret nærgående kritik af den måde, hvorpå uddelingen fandt sted. Det blev anført, at den foregik alt for langsomt, og at der ikke blev holdt fornøden kontrol med de mange biblioteker eller udarbejdet de fornødne kataloger. Nellemann foreslog at inddrage sognets kvinder $\mathrm{i}$ arbejdet. Det frarådede H.P. Hanssen, da det kunne medføre vanskeligheder med myndighederne.

Et vigtigt led i Sprogforeningens arbejde var endvidere udsendelsen af $» B o r$ nebladet «, gennem hvilket man udskrev danske stileopgaver til sønderjyske børn. Denne virksomhed fortsattes gennem hele perioden. De bedste stile blev belønnet med særlige boggaver, og det var medlemmer af studenterudvalget Heimdal, som påtog sig at rette stilene. Heimdalstudenterne blev også brugt til at katalogisere bøger og i det hele taget at indsamle og afsende egnet litteratur til Sprogforeningen til videre fordeling.

Engang imellem kom biblioteket på Margrethesminde ved Flensborg under debat, og der blev afgivet en nærmere redegørelse for dets indsats. Et vidnesbyrd om den betydning, forårsmøderne tillagde bogsagen, fremgår af det forhold, at man bad biblioteksagitatoren, overlærer Steenberg om på forårsmødet i 1905 at forelægge sine synspunkter med hensyn til den videre udbygning af de nordslesvigske biblioteker. Der måtte, hævdede han, fortsat skelnes mellem bogsamlingsbøger og gavebøger, og man burde foretrække letfattelige bøger med mange illustrationer. Der skulle i alle biblioteker være en grundstamme af de samme bøger, også omfattende moderne litteratur. Den mere videnskabelige litteratur burde samles på »Margrethesminde«. Steenberg tog endvidere til orde for oprettelse af læsekredse. På forårsmødet i 1909 gentog han sin anbefaling af læsekredsene, ligesom han berørte muligheden for ved de større købstadsbiblioteker at indrette små læsestuer.

Det andet centrale spørgsmål, som indgik som et fast punkt på dagsordenen, var problemerne omkring Skoleforeningens virksomhed. Forhandlingen begyndte normalt med, at Skoleforeningens mangeårige sekretær og kasserer Hinrich Thomsen-Roost gav en fyldig redegørelse for, hvor mange børn og unge, man havde været i stand til at sende af sted. Der var efterhånden oprettet en række efterskoler langs Kongeågrænsen, og hertil sendtes børnene fortrinsvis. Det var stadig således, at de fleste børn kom fra hjem i Haderslev amt, medens der kun var ganske få fra Flensborg amt. I 1901 således kun 4 elever. Foruden at sende børn på efterskole i kongeriget, understøttede man unge, der ville supplere deres skoleundervisning med et højskoleophold eller besøg 
på en landbrugsskole. Det var Skoleforeningens opfattelse, at ophold på en efterskole burde gå forud for et højskoleophold eller anden videregående uddannelse.

På mødet i 1901 spurgte dr. M. Mackeprang (1869-1959), der repræsenterede $4 \mathrm{~S}$, om man ikke skulle drage omsorg for, at der blev oprettet en efterskole på Fyn. Det ville være af stor interesse for eleverne fra Als og Sundeved, som på denne måde kunne opretholde en nær kontakt med hjemmet under opholdet $\mathrm{i}$ det fremmede. Gårdejer Nis Nissen (1862-1947) støttede forslaget, men det afvistes af Skoleforeningens ledelse. Rent principielt var man derimod enige om, at man måtte tilstræbe, at de efterskoler, man benyttede, ikke kun modtog sønderjyske børn. Det havde stor betydning for børnene fra Nordslesvig, at de under efterskoleopholdet havde kongerigske kammerater. Skoleforeningens succes fremkaldte også en vis frygt for, at de udsendte unge efter endt ophold i kongeriget ikke skulle vende tilbage til Nordslesvig. De hidtidige erfaringer havde imidlertid vist, at der ikke var nogen større risiko herfor. Højt regnet drejede det sig kun om ca. $1 \%$ af det samlede antal elever. Om størrelsen af det bidrag, som man udbetalte til den enkelte elev, meddelte Thomsen i 1902, at det i snit drejede sig om 130 mark. Dette beløb havde man udbetalt til 239 elever i 1902, men der var et betydeligt antal familier, som ikke havde haft behov for at få nogen hjælp, og som selv havde betalt for deres børn.

Også i denne periode interesserede Nellemann sig meget for, at man fortsatte de vellykkede rejser for landmand og husmaend. Som ny lokal leder af disse udflugter havde man fåt gårdejer Peter Grau, Pøl (1866-1953). Han var en af de mange nye gårdmænd, som i disse år mødte op til forårsmøderne. Den idérige Nellemann bragte i 1902 det spørgsmål under debat, om man ikke kunne invitere sønderjyske børn på sommerferie i kongeriget. Enkelte støttede tanken, men gårdejer Thomsen-Roost kunne meddele, at forældre til børn, som havde modtaget en sådan invitation, i visse tilfælde var blevet chikaneret af myndighederne. Nellemann meldte herefter, at han indtil videre ville lade sagen falde.

På flere møder gjorde de nordslesvigske repræsentanter, bl.a. gårdejer Skrumsager, opmærksom på, at den fremadskridende fortyskning af statskirken havde beklagelige følger. Ofte blev de sædvanlige søndagsgudstjenester kun overværet af ganske få medlemmer af menigheden. Man diskuterede oprettelsen af frimenigheder, men der var enighed om, at man ikke burde forcere udviklingen, da den jævne befolkning nødigt helt ville opgive statskirken.

Forhandlingerne om eventuel oprettelse af nye frimenigheder førte også ind på de ofte tilbagevendende diskussioner om forsamlingshusene. Der var imidlertid stor skepsis overfor at benytte forsamlingshusene til frikirkelige møder. H.P. Hanssen benyttede ofte forårsmøderne til at redegøre for forsamlingshus- 


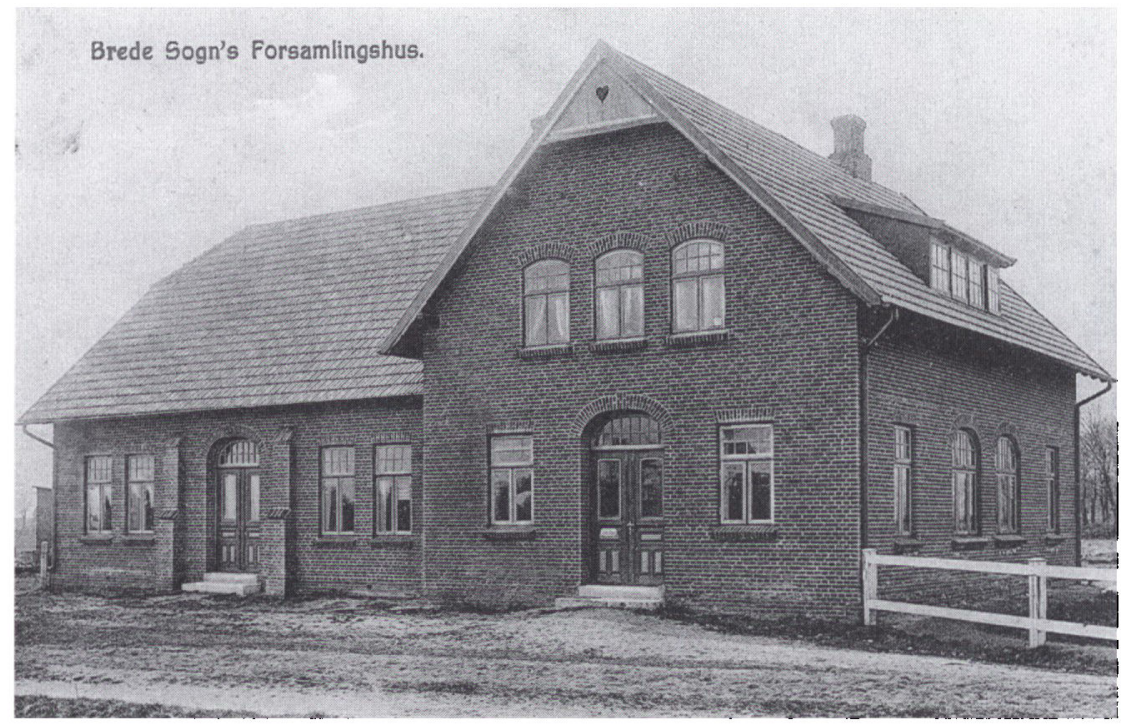

Forsamlingshusene blev ofte droftet pa forarsmoderne. Forsamlingshuset i Brede blev opfort 1907. Postkort $i$ Historiske Samlinger for Sonderjylland.

bevægelsen, som han tillagde den allerstørste betydning. I visse knudepunkter, understregede han, skulle man sørge for, at der blev opført større huse, f.eks. i Haderslev, Rødding og Skærbæk, og ude omkring i landdistrikterne burde der opføres så mange små huse som muligt. Forsamlingshusene skulle ikke blot anvendes til foredragsmøder og lignende. Man kunne også organisere gymnastikundervisning, anbringe den lokale bogsamling i husene, og endelig opføre amatørskuespil. Myndighederne havde efterhånden godkendt, at der kunne opkræves entré til de forskellige forestillinger, og man godkendte også servering, når blot der ikke blev udskænket spiritus.

Medens H.P.Hanssen i høj grad benyttede forårsmøderne til at holde de kongerigske repræsentanter løbende underrettet om de forskellige sider af nationalitetskampen, var det sjældent, at red. Jessen tog ordet. I hvert fald optræder han meget sjældent i de bevarede mødereferater. I 1902 tog han imidlertid ordet for Flensborg bys sag. Han kritiserede, at Sprogforeningen ved sine bogudsendelser især koncentrerede sig om de nationalt stærke egne og kun uddelte bøger i de noget fjerne egne, inclusive Flensborg, når man direkte bad om det. Flensborg hørte jo også med til »de truede områder «, udtalte han. I det hele taget var den nationale stilling i Flensborg vanskelig. Ganske vist kunne man glæde sig over, at Flensborg Avis havde fremgang, men det så sløjt ud med hensyn til det danske foreningsliv, og han pegede på, at det traditionelle 
St. Knuds gilde nu kun havde 9 medlemmer. Det ville utvivlsomt have stor betydning, hvis man kunne få skrevet gildets traditionsrige historie. Professor Nyrop lovede på stedet at drage omsorg for, at en sådan historisk fremstilling skulle blive forfattet.

Ved det samme forårsmøde udtalte Jessen, at han ikke var særlig glad ved forårsmøderne, da de ofte kolliderede med hans virksomhed i den tyske rigsdag, og i det hele taget burde man kun beskæftige sig med rent kulturelle og ikke med politiske spørgsmål. Herimod protesterede H.P. Hanssen, der havde en mere liberal fortolkning af begrebet politik. Absolut udelukket var blot emnet: Sønderjyllands genforening med Danmark. Som afslutning på denne debat gjorde Nellemann opmærksom på, at forårsmøderne først og fremmest havde til formål at holde de kongerigske medlemmer løbende underrettet om, hvad der skete i landsdelen. Det var en absolut nødvendighed.

Denne indstilling var formodentlig baggrunden for, at Nellemann på forårsmødet i 1909 foranledigede, at man i bred almindelighed diskuterede danskhedens stilling $\mathrm{i}$ de forskellige nordslesvigske købstæder. Som indledning gav H.P. Hanssen et billede af den aktuelle situation. Udvandringen havde $i \mathrm{~h}$ øj grad svækket købstæderne, men en vis bedring var indtrådt på det seneste. Han gjorde opmærksom på, at polakkerne indenfor det tyske rige langt bedre havde forstået at udvikle en levedygtig industri. Man burde i fremtiden interessere sig meget mere for oplæring af danske handelslærlinge. En del håndværkere var blevet uddannet $i$ kongeriget, men der burde gøres mere rent lokalt, og man måtte ofre mere på udviklingen af de udprægede byerhverv. Indledningen gav anledning til en meget livlig diskussion med 9 deltagere. Desværre har referenten forholdt os enhver antydning af, hvad der blev sagt.

\section{Mødernes betydning}

De såkaldte forårsmøder var et nyttigt samarbejdsorgan mellem sønderjysk interesserede kredse $\mathrm{i}$ kongeriget og den sønderjyske befolkning. Trods politiske modsætninger fortsatte samarbejdet så godt som usvakket op til verdenskrigens udbrud i sommeren 1914. Formålet med de mange møder var at koordinere ønsker fra Sønderjylland med den støtte - først og fremmest i form af kontant hjælp - man kunne fremskaffe fra de kongerigske foreninger.

Foruden denne rent praktiske opgave havde forårsmøderne den betydning, at de åbnede mulighed for et regelmæssigt og nært personligt samkvem mellem parterne. Man lærte hinanden at kende, hvilket kun kunne styrke sammenholdet. På grund af det stigende pres fra de preussiske myndigheder mod lokalbefolkningen $\mathrm{i}$ årene frem mod århundredskiftet, som kulminerede under Køller- 
perioden, gik man i begyndelsen stille med dørene. Man modtog kun et begrænset antal nordslesvigere og kun sådanne, på hvis diskretion man kunne regne. Efter århundredskiftet ændredes situationen. Antallet af deltagere fra begge sider steg fra møde til møde, og dette kunne ikke undgå i nogen grad at ændre hele mødeforløbet. Medens man indenfor den begrænsede kreds $\mathrm{i}$ 1890 'erne havde haft mulighed for virkelige drøftelser, blev det $i$ de senere år først og fremmest til afgivelse af en række rapporter fra ledende nordslesvigske repræsentanter om aktuelle emner. Der blev af og til stillet enkelte spørgsmål til disse, men det store flertal af forsamlingen holdt sig passiv. Det gælder både sønderjyderne og de kongerigske repræsentanter. Desuagtet må man nok hævde, at forårsmøderne har haft deres betydning for nationalitetskampen $\mathrm{i}$ Sønderjylland.

\section{NOTER OG HENVISNINGER}

1. Om foreningen TO LØVER's oprettelse og virksomhed indtil 1914, se det af foreningen i 1988 ved Harald Jørgensen udgivne jubilæumsskrift »I grænselandets tjeneste. TO LØVER « s. 13-33.

2. Om baggrunden for tidsskriftets oprettelse, se min afhandling i Sønderjyske Årboger 1964 s. 1126.

3. Bestyrelsesprotokol 1888-1901 s. 99 . Se også note 4.

4. TO LøVERS foreningsarkiv bærer Rigsarkivets arkivnr. 10.074. Foruden bestyrelsesprotokoller indeholder arkivet også en del korrespondancesager vedr. forårsmøderne. Den ældste bestyrelsesprotokol dækker årene 1888-1901 og citeres i det flg.: Bestyrelsesprotokol.

5. Bestyrelsesprotokol s. 19.

6. A.D. Jørgensens breve, udg. af Den danske historiske Forening $\mathrm{i}$ hundredåret for dens stiftelse ved Harald Jørgensen, 1939, s. $257 f$.

7. Anna Thalbitzer, født 1847 som datter af oberst Johan C. T.Thalbitzer (1814-88), sogte en larerindeplads hos gårdejer Skrumsager og motiverede sin ansøgning med, at mdet bedste i mit Sind og min Tanke drages til mine danske Landsmand $\mathrm{i}$ Sønderjylland og at måtte få lov at bo og bygge hos dem « (brev dat. 11,3.1885 i Skrumsagers arkiv i landsarkivet i Aabenraa). Hun fik ikke stillingen. Hun besøgte Skrumsager i 1885, og hun kontaktede også andre nordslesvigere. Frk. Thalbitzer havde ligeledes i 1884 taget initiativet til oprettelsen af Sønderjysk Samfund, der samlede ca. 500-600 mennesker til foredrag om sønderjyske emner. ADJ. holdt her en rakke foredrag. medens hans ungdomsven, murermester Karl Kruse, tog sig af det praktiske. Se ADJ.: En redegørelse for min udvikling og mit forfatterskab, $1901 \mathrm{~s}$. 151.

8. Der findes referater i bestyrelsesprotokollen af mødet i 1890 s. $20-28,1891$ s. $46-55,1892$ s. $73-$ 79, 1893 s. $81-84,1894$ s. $90-93$ og 1897 s. 136-47.

9. Se min afhandling i tidsskriftet Arkiv bd. 12, 1989, s. 156-69.

10. Bestyrelsesprotokol 1901-18 s. 150 .

11. Der findes referater i bestyrelsesprotokollen $1888-1901$ af mødet i $1898 \mathrm{~s} .169-89$ og $1900 \mathrm{~s} .254-$ 63. Herefter henvises til bestyrelsesprotokollen 1901-18, hvor mødet i 1901 er refereret s. 6-16, 1902 s. 3 l- 40,1903 s. $48-54,1905$ s. $60-65,1907$ s. $84-87$ og 1909 s. 115-22. 